\title{
Atrial flutter as a rare manifestation of leptospirosis
}

\author{
Sammantha J Kouba, ${ }^{1}$ Takaaki Kobayashi $\left(10,{ }^{2}\right.$ Robert J Blount, ${ }^{3}$ Loreen Herwaldt ${ }^{2}$
}

'Infectious Diseases, The University of lowa Hospitals and Clinics, lowa City, lowa, USA ${ }^{2}$ Internal Medicine, University of lowa Hospitals and Clinics, lowa City, lowa, USA

${ }^{3}$ Pulmonary and Critical Care Medicine, The University of lowa Hospitals and Clinics, lowa City, lowa, USA

Correspondence to Dr Sammantha J Kouba; Sammantha.Kouba@gmail.com

Accepted 27 July 2020

Check for updates

(c) BMJ Publishing Group Limited 2020. No commercial re-use. See rights and permissions. Published by BMJ.

To cite: Kouba SJ

Kobayashi T, Blount RJ,

et al. BMJ Case Rep

2020:13:e237693.

doi:10.1136/bcr-2020-

237693

\section{DESCRIPTION}

A 50-year-old healthy man presented with fever and chills after returning from Vietnam. While running around an urban water reservoir, he fell and sustained abrasions to his knee and elbow. He cleaned his injuries with dew and reservoir water. Approximately 14 days later, he began experiencing fever, chills, headache, dizziness and severe body aches. After two syncopal episodes, he presented to an urgent care clinic which promptly referred him to our clinic. Physical examination revealed a temperature of $39.1^{\circ} \mathrm{C}$, bradycardia, an irregular rhythm and right upper quadrant tenderness. Laboratory results included a low white cell count of $2.7 \times 10^{9} / \mathrm{L}$ (normal value $3.7-10.5 \times 10^{9} / \mathrm{L}$ ), a low platelet count of $121 \times 10^{9} / \mathrm{L}$ (normal value $\left.150-400 \times 10^{9} / \mathrm{L}\right)$, high aspartate aminotransferase $313 \mathrm{U} / \mathrm{L}(10-40)$, high alanine aminotransferase $223 \mathrm{U} / \mathrm{L}(10-41)$, high alkaline phosphatase $172 \mathrm{U} / \mathrm{L}$ (40-129), and normal bilirubin and creatinine. An abdominal ultrasound revealed an edematous gallbladder wall without evidence of cholelithiasis. ECG revealed new onset atrial flutter and variable atrioventricular nodal conduction with heart rate ranging from 35 to $55 / \mathrm{min}$ (figure 1). Leptospirosis IgM antibody by dot blot and chikungunya, rickettsia and Lyme disease serologies were negative. A Leptospira microscopic agglutination test (MAT) from the Centers for Disease Control and Prevention was also negative at less than 1:100. The patient was started on doxycycline empirically, given a high suspicion for leptospirosis. He underwent successful cardioversion. His symptoms continued to improve with doxycycline and he completed a 10-day course. A follow-up leptospirosis IgM titre obtained 2 weeks later was positive. Repeat MAT was positive at 1:3200 (32-fold increase). During a 16-month follow-up visit, the patient was asymptomatic and he was in sinus rhythm.

Leptospirosis is a widespread zoonotic disease caused by pathogens of the genus Leptospira. More than 1 million cases are estimated to occur

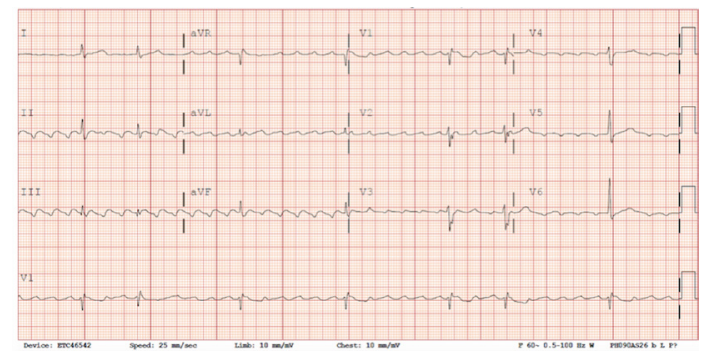

Figure 1 ECG showed new atrial flutter and variable atrioventricular nodal conduction with heart rate ranging from 35 to $55 / \mathrm{min}$.

\section{Learning points}

- Leptospirosis, which is caused by pathogens of the genus Leptospira, can range in severity from a mild febrile illness to severe, life-threatening disease.

- Leptospirosis rarely causes cardiac manifestations including various arrhythmias, myocarditis, pericarditis and endocarditis.

- Paired acute and convalescent antibodies should be obtained to diagnose leptospirosis.

worldwide each year. ${ }^{1}$ Transmission occurs seasonally, most commonly during the rainy season, via direct contact with urine, blood or tissue of infected animals or via contact with contaminated freshwater. ${ }^{2}$ Infection may range from asymptomatic to life-threatening. Symptoms typically arise 7-12 days following exposure but can develop from 3 days to 1 month after exposure. ${ }^{3}$ While a non-specific febrile illness is the most common manifestation, a small percentage of patients develops severe disease involving multiple organ systems. Although rare, leptospirosis can also affect the heart. Cardiac manifestations range from non-specific electrocardiographic changes and arrhythmias to myocarditis, pericarditis, endocarditis and cardiogenic shock. ${ }^{4-6}$ The electrocardiographic changes generally resolve completely after successful treatment and clinical recovery. ${ }^{7}$ Early diagnosis requires a high degree of suspicion as symptoms can be non-specific. A leptospirosis diagnosis guideline has not been published. Nevertheless, this infection is generally diagnosed by isolating Leptospira spp. from a normally sterile site or documenting a fourfold increase in the MAT titre from the acute-phase to the convalescent-phase serum sample or a single MAT titre of $\geq 1: 400$. ${ }^{8}$ Since the MAT is not readily available, alternative rapid tests are often used including IgM ELISA or molecular tests such as PCR. While serology is the most common initial method for diagnosing leptospirosis, the usefulness of serologic testing for the diagnosis of acutely ill patients is limited by delayed antibody appearance (day 5 to 7 after the onset of illness) among naive persons and by background seropositivity in endemic areas. ${ }^{9}$ Therefore, paired acute and convalescent samples should be obtained as we did for our patient. Molecular testing, such as PCR, provides results faster than serology and does not require paired acute and convalescent samples. The sensitivity of PCR is only $53 \%$ while the specificity is $97 \% .^{8}$ Early initiation of antimicrobial therapy may prevent some patients from progressing to severe disease. ${ }^{2}$ Mild disease is usually treated with 7 days of doxycycline or penicillin, whereas 
severe disease is typically treated with parenteral penicillin or a third-generation cephalosporin.

Contributors SK wrote the first draft of the manuscript. TK, LH and RB critically reviewed and revised the manuscript. All authors read and approved the final paper.

Funding The authors have not declared a specific grant for this research from any funding agency in the public, commercial or not-for-profit sectors.

Competing interests None declared.

Patient consent for publication Obtained.

Provenance and peer review Not commissioned; externally peer reviewed.

ORCID iD

Takaaki Kobayashi http://orcid.org/0000-0003-4643-4798

\section{REFERENCES}

1 Costa F, Hagan JE, Calcagno J, et al. Global morbidity and mortality of leptospirosis: a systematic review. PLoS Negl Trop Dis 2015;9:e0003898.
2 Haake DA. Levett PN: leptospirosis in humans. Curr Top Microbiol Immunol 2015;387:65-97.

3 Priya SP, Sakinah S, Sharmilah K, et al. Leptospirosis: molecular trial path and immunopathogenesis correlated with dengue, malaria and mimetic hemorrhagic infections. Acta Trop 2017;176:206-23.

4 Dussarat GV, Cointet F, Capdevielle P, et al. [Cardiac manifestations in leptospirosis. Apropos of 15 cases observed in New Caledonia]. Ann Cardiol Angeiol 1988;37:449-53.

5 Lee MG, Char G, Dianzumba S, et al. Cardiac involvement in severe leptospirosis. West Indian Med J 1986;35:295-300.

6 Ramachandran S, Perera MV. Cardiac and pulmonary involvement in leptospirosis. Trans R Soc Trop Med Hyg 1977;71:56-9.

7 Navinan MR. Rajapakse S: cardiac involvement in leptospirosis. Trans $R$ Soc Trop Med Hyg 2012;106:515-20.

8 Limmathurotsakul D, Turner EL, Wuthiekanun V, et al. Fool's gold: why imperfect reference tests are undermining the evaluation of novel diagnostics: a reevaluation of 5 diagnostic tests for leptospirosis. Clin Infect Dis 2012;55:322-31.

9 Schreier S, Doungchawee G, Chadsuthi S, et al. Leptospirosis: current situation and trends of specific laboratory tests. Expert Rev Clin Immunol 2013;9:263-80.

Copyright 2020 BMJ Publishing Group. All rights reserved. For permission to reuse any of this content visit

https://www.bmj.com/company/products-services/rights-and-licensing/permissions/

BMJ Case Report Fellows may re-use this article for personal use and teaching without any further permission.

Become a Fellow of BMJ Case Reports today and you can:

- Submit as many cases as you like

- Enjoy fast sympathetic peer review and rapid publication of accepted articles

- Access all the published articles

- Re-use any of the published material for personal use and teaching without further permission

\section{Customer Service}

If you have any further queries about your subscription, please contact our customer services team on +44 (0) 2071111105 or via email at support@bmj.com.

Visit casereports.bmj.com for more articles like this and to become a Fellow 